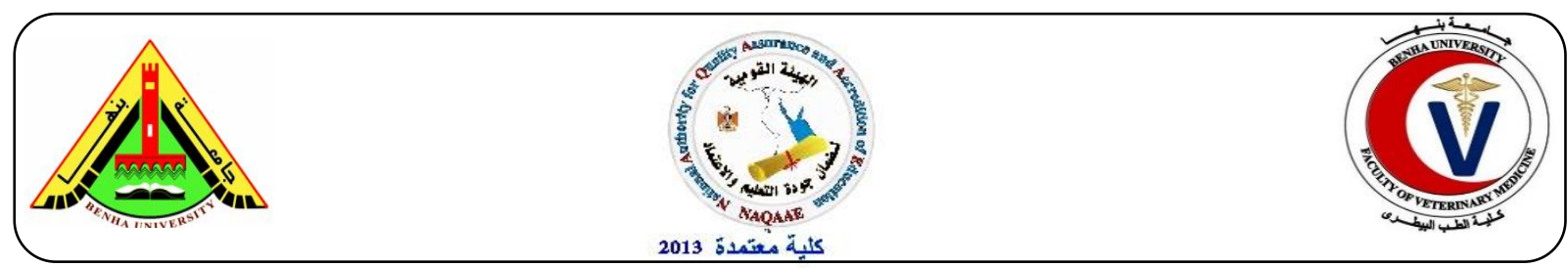

\title{
Studies on bacteriological profile of chicken meat cuts in Kaliobia governorate
}

\author{
Fatin S. Hassanen ${ }^{1}$, Fahem A. Shaltout ${ }^{1}$, Amani, M. S. ${ }^{2}$, Maarouf, A. A. A. ${ }^{2}$, Rasha, N. \\ $\mathbf{A}^{2}$ \\ ${ }^{1}$ Food hygiene Dept., Faculty of Veterinary Medicine, Benha University. ${ }^{2}$ Animal Health Research \\ Institute, Benha Branch - Food Hygiene Dept.
}

\begin{abstract}
A B S T R A C T
The study was performed on 120 random samples of fresh chicken meat cuts of Drumstick, thigh and breast (40 of each) purchased from different supermarkets and retail chicken butchers in Kaliobia governorate to evaluate their bacterial contamination. The bacteriological examination revealed that the mean values of APC, Staphylococci aureus counts (cuf/g) in drumstick samples were $7.47 \times 10$ ${ }^{4} \pm 0.31 \times 10^{4} ; 2.31 \times 10^{3} \pm 0.11 \times 10^{3} \& 0.26 \times 10^{3} \pm 0.07 \times 10^{3}, 6.51 \times 10^{4} \pm 0.30 \times 10^{4} ; 2.21 \times 10^{3} \pm 0.11 \times 10^{3}$ in thigh\& $0.22 \times 10^{3} \pm 0.07 \times 10^{3}$, and $6.13 \times 10^{4} \pm 0.32 \times 10^{4} ; 1.99 \times 10^{3} \pm 0.09 \times 10^{3} \& 0.19 \times 10^{3} \pm 0.06 \times 10^{3}$ in breast samples، respectively. Coagulase positive aureus strains were isolated from the examined fresh chicken meat cuts represented as $32.5 \%$ in drumstick $27.5 \%$ in thigh and $22.5 \%$ in breast samples. The isolated strains were highly resistant for methicillin followed by oxacillin; ampicillin; cefotaxime and amoxicillin. Meanwhile, they were highly sensitive to ciprofloxacin followed by enrofloxacin and gentamycin.
\end{abstract}

Keywords: Chicken meat, Bacteriological evaluation, S. aureus

(http://www.bvmj.bu.edu.eg)

(BVMJ 33, (2): 402-409, 2017

\section{INTRODUCTION}

Chicken meat is a nutritious, healthy food that is low in fat and cholesterol compared to other meats as well as it is an excellent source of protein. On the other hand, it is an ideal medium for bacterial growth because of high moisture content, richness in nitrogenous compounds (essential amino acids, proteins), good source of minerals, vitamins and other growth factors. Furthermore, its $\mathrm{pH}$ is favorable for the growth of microorganisms.

Both poultry muscle and skin are excellent substrates for supporting the growth of a wide variety of microorganisms, especially, Staphylococci mainly S. aureus that considered as one of the most important causes of foodborne outbreaks in people (Prange et al., 2005 and Bhaisare et al., 2014).
Chicken meat may be contaminated at any stage of the production process, from feather plucking, evisceration and washing until storage by chilling or freezing. Microorganisms from the environment, equipment and operator's hands can also contaminate poultry meat possible at any stage of the production process, from feather plucking, evisceration and washing until storage by cooling or freezing. Microorganisms from the environment, equipment and operator's hands can contaminate poultry meat (Živković, 2001).

$S$. aureus is considered an excellent indicator of thermal processing inefficiency, inadequate hygienic conditions during food production/ preparation or inadequate cooling after food preparation (Malheiros et al., 2010; 
Alexandra et al., 2011 and Sasidharan et al., 2011). S. aureus produces a wide variety of enterotoxins (SEs; SEA to SEE, SEG, SEI, SER, SET) with demonstrated emetic activity (María et al., 2010). The Staphylococcal enterotoxins (SEs) are responsible for the symptoms that associated with Staphylococcal food poisoning (Llewelyn and Cohen, 2002). Such poisoning is characterized by rapid onset symptoms including nausea, violent vomiting, abdominal cramps and diarrhea lasting from 24 to $48 \mathrm{~h}$ and the complete recovery usually occurs within 1-3 days. The illness is usually self-limiting and only occasionally it is severe enough to warrant hospitalization. Moreover, sea is the most common enterotoxin recovered from food poisoning outbreaks (Pinchuk et al., 2010; María et al., 2010 and Shijia et al., 2016).Therefore, this study was performed for detection the prevalence of Staphylococci with special reference to coagulase positive $S$. aureus beside the phenotypic characterization of the isolated $S$. aureus strains and detection of sensitivity against various antibiotics.

\section{MATERIAL AND METHODS}

\subsection{Samples collection}

A total of 120 random samples (about 250 $\mathrm{g}$ for each) of fresh chicken meat cuts represented by Drumstick, thigh and breast (40 of each) purchased from different supermarkets and retail chicken butchers in Kaliobia governorate for bacteriological examination.

\subsection{Bacteriological examination}

\section{Preparation of samples (APHA, 2001)}

Twenty five grams of the sample were taken under aseptic condition to sterile Stomacher bag then $225 \mathrm{ml}$ sterile $0.1 \%$ peptone water were added. The contents were homogenized at Stomacher (M A 106402France, 450 to 640 strokes per minute) for 2 minutes and the mixture was allowed to stand for 5 minutes at room temperature. The contents were transferred into sterile flask and thoroughly mixed by shaking and $1 \mathrm{ml}$ was transferred into separate tube each containing $9 \mathrm{ml}$ sterile $0.1 \%$ peptone water, from which tenth- fold serial dilutions were prepared. The prepared samples were subjected to the following bacteriological examination:

2. Determination of Aerobic Plate Count (APC) using the standard plate count following (FDA, 2001).

3. Determination of Staphylococcus and $S$. aureus counts (FDA, 2001)

4. Isolation and identification of suspected S. aureus:

Isolation of $S$. aureus was done using Baird-Parker Agar Plates. Suspected colonies were picked up onto slants of nutrient agar for further purification then identified morphologically by Gram-stain; biochemically and coagulase activities according to ICMSF (1996) and Quinn et al., (2002).

5. In-Vitro anti-microbial sensitivity test:

The isolated $S$. aureus strains were subjected to the sensitivity test against different antibiotics, using the disc and agar diffusion method (Koneman et al., 1997).

\section{RESULTS}

It is evident from the result recorded in table (1) that the mean values of APC (cfu/g) in the examined samples of fresh chicken meat cuts (drumstick, thigh and breast) were $7.47 \times 10^{4} \pm 0.31 \times 10^{4}$; $6.51 \times 10^{4} \pm 0.30 \times 10^{4}$ and $6.13 \times 10^{4} \pm 0.32$ $\times 10^{4}$ respectively.

However, All samples were acceptable, as these counts were lower than those suggested by EOS (4178/2005)(10 cfu/g). Moreover, the statistical results revealed that, fresh drumstick samples showed a significant $(\mathrm{P} \leq 0.05)$ increase of APC when compared with other ones. Moreover, there were no significant difference $(\mathrm{P}>0.05)$ of APC between fresh thigh and breast samples.

The obtained results in Table (2) revealed that, the average Staphylococcus count $(\mathrm{cfu} / \mathrm{g})$ in the drumstick, thigh and breast samples were $2.31 \times 10^{3} \pm 0.11 \times 10^{3}$; 
$2.21 \times 10^{3} \pm 0.11 \times 10^{3}$ and $1.99 \times 10^{3} \pm 0.09$ $\times 10^{3}$, respectively. Moreover, the statistical results revealed that, fresh drumstick samples showed a significant $(\mathrm{P} \leq 0.05)$ increase of Staphylococci counts when compared with other ones. However, there were no significant difference $(\mathrm{P}>0.05)$ of Staphylococci counts between fresh breast and fresh thigh samples.

The recorded results in Table (3)declared that the mean value of S.aureus count $(\mathrm{cfu} / \mathrm{g})$ in the examined fresh drumstick, thigh and breast samples were $0.26 \times 10^{3}$ $\pm 0.07 \times 10^{3} ; 0.22 \times 10^{3} \pm 0.07 \times 10^{3}$ and $0.19 \times 10^{3} \pm 0.06 \times 10^{3}$, respectively. The incidence of S.aureus were $13(32.5 \%)$ in drumstick, $11(27.5 \%)$ in thigh and $9(22.5 \%)$ in breast samples.

According to safe permissible limits stipulated by EOS (1090/2005) for the $S$. aureus count (free). All samples were unaccepted. Moreover, there was no significant difference of $S$. aureus counts between examined samples of fresh drumstick, thigh and breast samples.
The results obtained in Table (4) illustrated that, 33 isolates of Coagulase positive S.aureus were isolated from examined fresh chicken meat cuts (drumstick, thigh and breast samples represented as $13(32.5 \%)$ from drumstick samples; $11(27.5 \%)$ from thigh samples and $9(22.5 \%)$ from breast samples. Moreover, $72.5 \%$ of samples were accepted (Fig. 5), as they were free from Coagulase Positive S.aureus isolates according to EOS (1090, 2005).

Results in (Table, 6) showed that, the isolated S.aureus were highly resistant for methicillin (87.9\%) followed by oxacillin $(84.9 \%)$; ampicillin $(66.7 \%)$; cefotaxime $(63.6 \%)$ and amoxicillin (60.6\%). Meanwhile, the isolated $S$. aureus strains were highly sensitive to ciprofloxacin $(84.9 \%)$ followed by enrofloxacin $(81.8 \%)$ and gentamycin $(78.8 \%)$. Moreover, they were intermediate sensitive to sulfatrimethoprim (69.7\%); neomycin (66.7\%); erythromycin $(60.6 \%)$ and streptomycin (57.6\%).

Table (1): Mean values of Aerobic plate counts. (cfu/g) in the examined samples of fresh chicken meat cuts $(n=40)$

\begin{tabular}{lccc}
\hline Sample & Min. & Max. & Mean $\pm \mathrm{SEM}^{* *}$ \\
\hline Drumstick & $2.2 \times 10^{4}$ & $1.05 \times 10^{5}$ & $7.47 \times 10^{4} \pm 0.31 \times 10^{4 \mathrm{a}}$ \\
Thigh & $2.4 \times 10^{4}$ & $9.5 \times 10^{4}$ & $6.51 \times 10^{4} \pm 0.30 \times 10^{4 \mathrm{~b}}$ \\
Breast & $1.6 \times 10^{4}$ & $9.4 \times 10^{4}$ & $6.13 \times 10^{4} \pm 0.32 \times 10^{4 \mathrm{~b}}$ \\
\hline
\end{tabular}

* Percentage in relation to total number of sample in each row.**Standard error of mean Significant difference of fresh drumstick samples $(\mathrm{P} \leq 0.05)$. No significant difference between fresh thigh and breast samples $(\mathrm{P}>0.05)$

Table (2): Mean values of Staphylococci counts(cfu/g) in the examined samples of fresh chicken meat cuts $(n=40)$

\begin{tabular}{lccc}
\hline Samples & Min. & Max. & Mean \pm SEM** $^{* *}$ \\
\hline Drumstick & $1.5 \times 10^{3}$ & $4.1 \times 10^{3}$ & $2.31 \times 10^{3} \pm 0.11 \times 10^{3 \mathrm{a}}$ \\
Thigh & $1.0 \times 10^{3}$ & $4.1 \times 10^{3}$ & $2.21 \times 10^{3} \pm 0.11 \times 10^{3 \mathrm{ab}}$ \\
Breast & $0.9 \times 10^{3}$ & $3.6 \times 10^{3}$ & $1.99 \times 10^{3} \pm 0.09 \times 10^{3 \mathrm{~b}}$ \\
\hline
\end{tabular}

\footnotetext{
* Percentage in relation to total number of sample in each row.**Standard error of mean Significant difference of fresh drumstick samples $(\mathrm{P} \leq 0.05)$. No significant difference between fresh thigh and breast samples $(\mathrm{P}>0.05)$.
} 
Table (3): Mean values of $S$. aureus counts (cfu/g) in the examined samples of fresh chicken meat cuts $(n=40)$

\begin{tabular}{llllllll}
\hline Samples & \multicolumn{2}{l}{ Negative } & \multicolumn{2}{l}{ Positive } & Min. & Max. & Mean \pm SEM $^{* *}$ \\
& No. & $\%^{*}$ & No. & $\% *$ & & & \\
\hline Drumstick & 27 & 67.5 & 13 & 32.5 & $<1 \times 10^{2}$ & $1.5 \times 10^{3}$ & $0.26 \times 10^{3} \pm 0.07 \times 10^{3 \mathrm{a}}$ \\
Thigh & 29 & 72.5 & 11 & 27.5 & $<1 \times 10^{2}$ & $1.5 \times 10^{3}$ & $0.22 \times 10^{3} \pm 0.07 \times 10^{3 \mathrm{a}}$ \\
Breast & 31 & 77.5 & 9 & 22.5 & $<1 \times 10^{2}$ & $1.3 \times 10^{3}$ & $0.19 \times 10^{3} \pm 0.06 \times 10^{3 \mathrm{a}}$ \\
\hline
\end{tabular}

* Percentage in relation to total number of sample in each row.**Standard error of mean Significant difference of fresh drumstick samples $(\mathrm{P} \leq 0.05)$. No significant difference between fresh thigh and breast samples $(\mathrm{P}>0.05)$.

Table (4): Acceptability of Coagulase Positive S. aureus examined samples of fresh chicken meat cuts $(n=40)$

\begin{tabular}{lcccc}
\hline Samples & \multicolumn{2}{c}{ Positive } & $\begin{array}{c}\text { No. of accepted } \\
\text { samples** }\end{array}$ & \% of accepted samples** \\
& No. & $\% *$ & & 32.5 \\
\hline Drumstick & 13 & 32.5 & 27 & 27.5 \\
Thigh & 11 & 27.5 & 29 & 22.5 \\
Breast & 9 & 22.5 & 31 & 27.5 \\
Total & 33 & 27.5 & 87 & \\
\hline
\end{tabular}

* Percentage in relation to total number of sample in each row, EOS $(4178,2005)$.

Table (5): Anti-microbial Sensitivity for isolated S.aureus strains

\begin{tabular}{lcccccccc}
\hline \multirow{2}{*}{ Antimicrobial agents } & Disk & \multicolumn{2}{c}{ Sensitive } & \multicolumn{2}{c}{ Intermediate } & \multicolumn{2}{c}{ Resistant } & \multirow{2}{*}{ AA } \\
\cline { 3 - 7 } & Concentrations & No. & $\%$ & No. & $\%$ & No. & $\%$ & \\
\hline Amoxicillin & $25 \mu \mathrm{g}$ & 5 & 15.2 & 8 & 24.2 & 20 & 60.6 & $\mathrm{R}$ \\
Ampicillin & $20 \mu \mathrm{g}$ & 11 & 33.3 & 0 & 0.0 & 22 & 66.7 & $\mathrm{R}$ \\
Cefotaxime & $30 \mu \mathrm{g}$ & 3 & 9.1 & 9 & 27.3 & 21 & 63.6 & $\mathrm{R}$ \\
Ciprofloxacin & $5 \mu \mathrm{g}$ & 28 & 84.9 & 4 & 12.1 & 1 & 3.0 & $\mathrm{~S}$ \\
Enrofloxacin & $5 \mu \mathrm{g}$ & 27 & 81.8 & 4 & 12.1 & 2 & 6.1 & $\mathrm{~S}$ \\
Erythromycin & $15 \mu \mathrm{g}$ & 5 & 15.2 & 20 & 60.6 & 8 & 24.2 & $\mathrm{IS}$ \\
Gentamicin & $10 \mu \mathrm{g}$ & 26 & 78.8 & 4 & 12.1 & 3 & 9.1 & $\mathrm{~S}$ \\
Methicillin & $5 \mu \mathrm{g}$ & 1 & 3.0 & 3 & 9.1 & 29 & 87.9 & $\mathrm{R}$ \\
Neomycin & $30 \mu \mathrm{g}$ & 4 & 12.1 & 22 & 66.7 & 7 & 21.2 & $\mathrm{IS}$ \\
Oxacillin & $1 \mu \mathrm{g}$ & 1 & 3.0 & 4 & 12.1 & 28 & 84.9 & $\mathrm{R}$ \\
Streptomycin & $\mathrm{S} / 10$ & 4 & 12.1 & 19 & 57.6 & 10 & 30.3 & $\mathrm{IS}$ \\
Sulfa-trimethoprim & $\mathrm{TMP5}$ & 6 & 18.2 & 23 & 69.7 & 4 & 12.1 & IS \\
\hline
\end{tabular}

No.: Number of isolates \%: Percentage in relation to total number of isolates (33).AA: Antibiogram activity, R: Resistant, S: Sensitive, I: Intermediate.

\section{DISCUSSION}

It is evident from the result recorded in table (1) that the total APC in examined samples nearly similar to that obtained by Marwan- Heba (2016) who revealed that, the mean value of APC/gfor fresh chicken meat were $\left(7.50 \times 10^{4} \pm 0.22 \times 10^{4}\right)$ While, the results disagreed with those of Mohamed (2016) who recorded higher count $\quad\left(3.78 \times 10^{6} \pm 0.93 \times 10^{6}\right) \quad$ Also, disagreed with Daoud (2012) who obtained lower counts were $\left(2.1 \times 10^{3}\right)$.

The higher aerobic plate count in chicken meat was due to slaughtering and sale of chicken meat in the same place, which provokes the cross contamination of the carcasses. Moreover, the carcasses are kept at ambient temperature, which allows the multiplication of mesophilic microorganisms Moreover, the chopping tables 
which manufactured from wood were found to be same every day without proper cleanliness. This enhanced the chance of cross contamination for uninfected carcass. As well as the processing of carcass into parts lead to further spread of contamination by exposing more carcass surface and susceptible fleshy parts to the contaminants if the same cutting tables and knives are used (Satin, 2002).

Table (2) indicated that the total Staphylococcus count were nearly similar to results that obtained by Marwan- Heba (2016) who found that the mean value of total Staphylococcus is $1.73 \times 10^{4} \pm 0.09$ $\left.\times 10^{4}\right)$. Meanwhile, the results disagreed with those of Saif-Marwa (2015) and Mohamed(2016)who reported higher Staphylococcus counts in examined samples $\left(6.88 \pm 0.01\right.$ and $2.50 \times 10^{4} \pm$ $\left.0.93 \times 10^{3}\right) \mathrm{cfu} / \mathrm{g}$ respectively. The increase of total Staphylococcal count indicates poor hygienic condition. In addition, it can occur at multiple steps along the food chain, which includes production, processing, distribution, retail marketing, handling and preparation.

The presence of $S$. aureus in foods commonly indicates direct contamination from worker's hands with abrasion and wounds or inadequately cleaned equipment resulting in S.aureus intoxication. Accordingly, S.aureus count can be taken as an index of sanitary conditions under which the meat and its products are manufactured and handled (potter, 2001).

It is obvious from results obtained in table (4) that total S.aureus counts were nearly similar to that recorded by Shareef et al. (2012) who reported that, S.aureus count was $\left(1.61 \pm 0.16 \log _{10} \mathrm{cfu} / \mathrm{cm}^{2}\right)$ Meanwhile, the results disagreed with those of SaifMarwa (2015) and Mohamed (2016) who reported higher $S$. aureus counts in examined samples of thigh and breast were $\left(1.14 \times 10^{4} \pm 0.85 \times 10^{3} \mathrm{cfu} / \mathrm{g}\right.$ and $1.12 \times 10^{4} \pm$ $0.83 \times 10^{3} \mathrm{cfu} / \mathrm{g}$ ) respectively.

Most previous studies were interested with coagulase Positive S.aureus strains of Staphylococci species as it is still a major cause of food poisoning due to ingestion of enterotoxin (Le Loir, 2003) and the ability to produce such enterotoxin in food is more likely when competing microorganisms were absent, resulting in symptoms of intoxication, not an infection and common symptoms appear approximately 3-8 hr. after ingestion as nausea, vomiting, abdominal cramps and diarrhea. Generally, symptoms are short in duration, "approximately 24-48hrs (Sandle and Mckillip, 2004).

It declared that results in table (4) of coagulase positive S.aureus came in accordance with those obtained by Shareef et al. (2012); and Marwan- Heba (2016). Meanwhile, these results were disagreed with those of Abo-Samra (2013); Abdalrahman et al., (2015); Ahmed (2015) and Moustafa et al. (2016) who isolated $S$. aureus from chicken meat samples with higher incidence and also, disagreed with Abd El- Fattah- Shereen (2014) who isolated $S$. aureus from chicken meat samples with lower incidence.

The presence of coagulase Positive $S$. aureus in poultry meat and its products indicates poor hygiene of meat handlers as well as lack of sterilization of utensils and they grow without pronounced change in odour or taste in the products and producing heat stable enterotoxins which lead to food poisoning with severe diarrhoea and gastroenteritis among consumers (Le Loir, 2003and Bakr et al 2004).

The widespread use of antibiotics has undoubtedly accelerated the virulence of $S$. aureus, by acquiring multiple resistance genes, has become able to survive almost all antibiotic families (Stefani and Goglio, 2010). Several workers have reported the occurrence of multidrug resistant S.aureus in poultry (Waters et al., 2011).

As shown in table (5) the antimicrobial sensitivity for isolated S.aureus strains were agreed with Akbar and Anal (2013); Abd El- Salam- Azza (2014); Ezzat et al. (2014); Abdalrahman et al.(2015) and Afifi-Dina (2016). In addition, the results 
proved that multiple antibiotic resistances are widely spread among isolated strains of S.aureus. Meanwhile, the isolated $S$. aureus strains were highly sensitive to ciprofloxacin $(84.9 \%)$ followed by enrofloxacin $(81.8 \%)$ and gentamycin (78.8\%). Moreover, they were intermediate sensitive to sulfa-trimethoprim (69.7\%); neomycin (66.7\%); erythromycin $(60.6 \%)$ and streptomycin $(57.6 \%)$. These results were agreed with Hansons et al.( 2011); Waters et al.( 2011); Al-Ghamdi ( 2012); Enany et al.(2013); Abdalrahman et al.(2015) and Afifi-Dina (2016) .

Finally, the results proved that multiple antibiotic resistances are widely spread among S.aureus isolated strains and decided the fact of Shalini and Rameshwar (2005) that the food chain can be considered as the main route of transmission of antibiotic resistant bacteria between the animal and human populations. Moreover, the present study proved that fresh chicken meat cuts are considered public health hazard and the presence of aerobic bacteria and Staphylococci mainly coagulase Positive $S$. aureus may be due to mishandling and the negligence of hygienic aspects.

\section{CONCLUSION}

we found that drum stick samples were more contaminated part than thigh and breast samples due to direct contamination from worker's hands with abrasion and wounds or inadequately cleaned equipment resulting in S.aureus intoxication .Accordingly, S.aureus count can be taken as an index of sanitary conditions under which the meat and its products are manufactured and handled.

\section{REFERENCES}

Abd El-Fattah-Shereen, A. Y. (2014): "Enteropathogenic bacteria in broiler carcasses and some poultry products". Ph. D. Thesis, Fac. Vet. Med. Alex. Uni.

Abdalrahman, L. S.; Stanley, A.; Wells, H. and Fakhr, M. K. (2015): "Isolation, virulence, and antimicrobial resistance of methicillin-resistant Staphylococcus aureus (MRSA) and methicillin sensitive Staphylococcus aureus (MSSA) Strains from Oklahoma retail poultry meats". Int. J. Environ. Res. Public Health, 12: 6148-6161.

Abdaslam, S. A.; Hassan, M. A.; Kaheel, H. A.;Abobaker, T. M.; Alnourain, T. H.; Hamdan, H. A.; Gokul Shankar, S. and Thambirajah, J. (2014): "Isolation of Escherichia coli $\mathrm{O}_{157}$ and other food borne pathogens from meat products and their susceptibility to different antimicrobial agents". Current Research in Microbiology and Biotechnology, 2 (3): 391-397.

Abo-Samra, R. G. (2013): "Staphylococcus aureus, Salmonella species and Listeria monocytogenes in locally fresh and frozen chicken meat in Dammietta city". Animal Health Research J.,1(2):1-10.

Afifi, Dina, H.M. (2016): Characterization of

Methicillin-Resistant Staphylococcus aureus (MRSA) isolated from food products of poultry origin In Egypt. M.V. Sc. Thesis (Bacteriology, Immunology and Mycology), Fac. Vet. Med., Benha Univ.

Ahmed-Alyaa,S.O.S.(2015):Quality of Native and Imported Meat in The Egyptians Markets .M.Sc. Thesis(Food Hygiene and Control) Fac. Vet. Med. Cairo University.

Akbar, A. 1. and Anal, A.K. (2013): Prevalence and antibiogram study of Salmonella and $S$. aureus in poultry meat. Asian Pac. J., 3(2):163-168.

Alexandra, F.; Britta, K.; Gladys, K.; Beatriz, G.R.; Katja, A.; Hammerl, J.A.; Annemarie, K.; Juliane, B.; Bernd, A. and Bernd-Alois, T. (2011): Methicillin susceptible and resistant Staphylococcus aureus from farm to fork impact on food safety. Tehnologii mesa, 52 (1): 60-65. 
Al-Ghamdi, A. Y. (2012): "Incidence of Staphylococcus aureus contamination of marketed processed chicken products with special reference to its antibiotics sensitivity collected from Al Baha city markets, Saudi Arabia". PAK. J. Food Sci., 22(3): 168-170.

American Public Health Association "APHA" (2001): Compendium of Methods for the Microbiological examination of Foods. $4^{\text {th }}$ Ed. F.P. Downes and K. Ito(editors), APHA. Washington D.C., USA.

Baker, M. D and Acharya, K. R (2004): Superantigens: structure function relationships. Int $J \mathrm{Med}$ Microbiol293: 529-537.

Bhaisare, D.B.; Richard, T.D. and Punniamurthy, C.N. (2014): Bacterial Pathogens in Chicken Meat: Review. International J. Life Sciences Research, 2(3): 1-7.

Daoud. J. R. (2012): Microbial quality of frozen chicken meat at grocery stores in Qena city, International Conference and Exhibition on Food Processing \& Technology.

Egyptian Organization For Standardization 'E.O.S, 1090' (2005): Egyptian Organization For Standardization and quality control. Egyptian Standards for frozen poultry and rabbit.

Egyptian Organization For Standardization 'E.O.S, కlv^', (2005):minced poultry and rabbit.

Enany, M. E.; Abd El Wanis, S. A.; ELGammal, A. M. and Abo Eillil, S. A. (2013): "Phenotypic and genotypic characterization of Methicillin resistant S. aureus (MRSA) isolated from broiler chickens of traditional poultry slaughter shops in Ismailia province". SCVMJ, XVIII (2): 189199.

Ezzat, M.; Shabana, I. I.; Riad, E. M. and Sarah,M.A. (2014): "Molecular characterization of Staphylococcus aureus isolated from meat, milk and their products". SCVMJ, 19(1): 137152.

Food and Drug Administration "FDA" (2001): Foodborne illness, what consumer need to know. USDA Food Saftey and Inspection Service.

Hanson, B. M.; Dressler, A. E.; Harper, A. L.; Scheibel, R. P.;Wardyn, S. E. and Roberts, L. K. (2011): "Prevalence of Staphylococcus aureus and methicillin-resistant Staphylococcus aureus (MRSA) on retail meat in Iowa". Journal of Infection and Public Health, 4: 169-174.

Ibrahim, M. I. A. (2013): Microbiological comparison between broiler chickens produced in poultry abattoir and private shops. Thesis Ph.D . Fac. Vet. Med. Alex. Univ.

International commission of Microbiological Specification for Foods "ICMSF" (1996): Microorganisms in Food. Their Significance and Methods of Enumeration. $3^{\text {rd }}$ Ed. Univ. of Toronto, Canada.

Konemann, E.; Allen, S.; Janda, W.; Schreckenberger, C. and Winn, W. (1997): "Color Atlas and Textbook of Diagnostic Microbiology". Fifth Edition. Lippincott, Philadelphia, New York.

Leloir, Y.; Baron, F. and Gautier, M. (2003): "Review: Staph. aureus and food poisoning". J. Genetics and Molecular Research, 2 (1): 63 - 76.

Lieweiyn, M. and Cohen, J. (2002): "Superantigens: Microbial agents that corrupt immunity". Lancet Infect Dis 2: $156-162$.

Malheiros, P.S.; Passos, C.T.; Casarin, L.S.; Serraglio, L. and Tondo, E.C. (2010): Evaluation of growth and transfer of Staphylococcus aureus from poultry meat to surfaces of stainless steel and polyethylene and their disinfection. Food Control, 21: 298-301.

María, Á. A.; María, C. M. and María, R. R. (2010): Food Poisoning and 
Staphylococcus aureus Enterotoxins. Toxins (Basel), 2(7): 1751-1773.

Marwan, Heba, A.I. (2016): Sanitary status of meat meals at hospital level in Kaliobia Governorate. M.V. Sc. Thesis (Meat Hygiene), Fac. Vet. Med., Benha Univ.

Mohamed, M.S.E. (2016): Frozen chicken meat in Quality Governmental hospital. M.V. Sc. Thesis (Meat Hygiene), Fac. Vet. Med., Benha Univ.

Moustafa, N. Y.; Abd El-Hafiz, Reham,M. and ElBahy, Engy F. (2016): Incidence of Staphylococcus aureus and Salmonella in Poultry Meat. Global Veterinaria, 16 (6): 570-578.

Pinchuk, I.V.; Beswick, E.J. and Reyes, V.E. (2010): Staphylococcal Enterotoxin. Toxins (Basel), 2(8): 2177-2197.

Potter, N. N. (2001): "Food Science". 3rd Ed. The AVI Publishing Co., INC. New York, USA.

Prange, A.; Birzele, B.; Hormes J. and Modrow, H. (2005):Investigation of different human pathogenic and food contaminating bacteria and mould grown on Selenite/ Selenate and Tellurite / Tellurate by-x ray absorption spectroscopy. Food Control, 16: 713-728.

Quinn, P. J., Markey, B. K., Carter, M. E., Donnelly, W. J. C., Leonard, F. C. and Maguire, D. (2002): "Veterinary microbiology and microbial disease". Iowa State Univ. Press, Blackwell Science Ltd, chapters 26-36: 84-96.

Saif-Marwa, Z. M. A. (2015): "Bacterial Status of Fresh Marketed chicken cuts". M. V. Sc. Thesis, Meat Hygiene, Fac. of Vet. Med. Moshtohor. Benha Univ.

Sandel, M. K. and Mckillip, J. L. (2004): "Virulence and recovery of Staphylococcus aureus relevant to the food industry using improvements on traditional approaches". J. Food Control, 15:5-10.
Satin, M. (2002): Use of irradiation for microbial decontamination of meat: Situation and perspectives. J. Meat Sci., 62: 277-283.

Sasidharan, S.; Prema, B. and Yoga Ltha, L. (2011): Antimicrobial drug resistance of Staphylococcus aureus in dairy products. Asian Pcific Journal of Tropical Biomiedicine: 130-132.

Shalini, M. and Rameshwar, S. (2005): "Antibiotic resistance in food lactic acid bacteria - a review". International Journal of Food Microbiology, 105:281-295.

Shareef, A.M; Farag, R.A and AlRuthwani, E.K (2012): Evaluation of bacterial load of frozen chicken thighs in Mosul markets. Iraqi, J. Vet. Sci., Vol.26, Supplement II, 2012(63-69), Proceedings of the $6^{\text {th }}$ Scientific Conference, College Of Veterinary Medicine, University of Mosul.

Shijia, W. ; Nuo, D. ; Huajie, G.; Liling H.; Hua Y., Wenhui, G. and Zhouping W.(2016): A review of the methods for detection of Staphylococcus aureus Enterotoxins. Toxins, 8, 176; doi:10.3390/toxins 8070176 .

Stefani, S. and Goglio,A.( 2010): Methicillin-resistant Staphylococcus aureus: Related infections and antibiotic resistance. Int. J. Infect. Dis., 14: 19- 22.

Waters, A.E.; Contente-Cuomo, T.; Buchhagen, J.; Liu, C.M.; Watson, L. and Pearce, K.(2011): MultidrugResistant Staphylococcus aureus in US Meat and Poultry. Clin. Infect. Dis., 52 (10):1227-1230.

Živković, J. (2001) Higijena i tehnologija mesa. Veterinarskosanitarninadzorživotinjazaklanje i mesa. I. dio. II. dopunjenoizdanje. Uredio i dopunio M. Hadžiosmanović.

VeterinarskifakultetSveučilišta $u$ Zagrebu. 